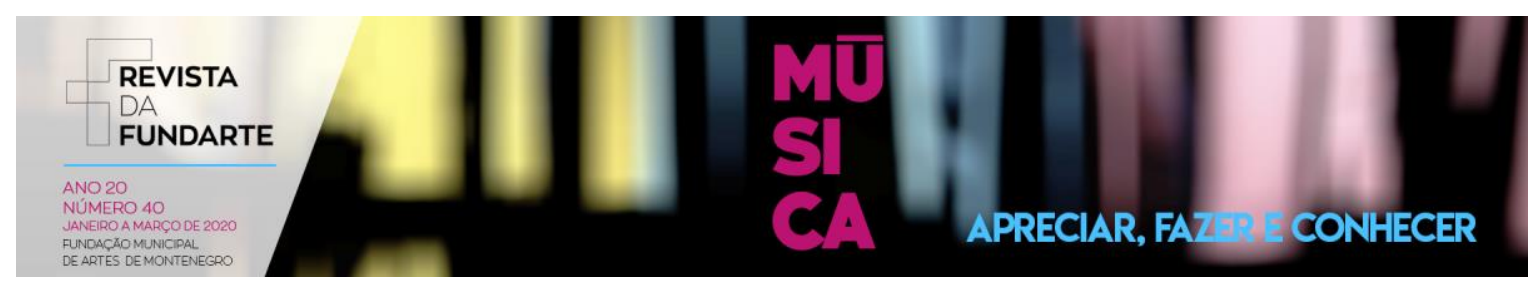

\title{
O CICLO DA ABORDAGEM CURRICULAR EM EDUCAÇÃO MUSICAL
}

\author{
Bruno Felix da Costa Almeida
}

DOI: http://dx.doi.org/10.19179/2F2319-0868/2F764

ALMEIDA, Bruno Felix da Costa Almeida. .O ciclo da abordagem curricular em educação musical. Revista da FUNDARTE. Montenegro, p.87-109, ano 20, no 40, janeiro/março de 2019. Disponível em: http://.seer.fundarte.rs.gov.br/index.php/RevistadaFundarte/index> 31 de março de 2020 


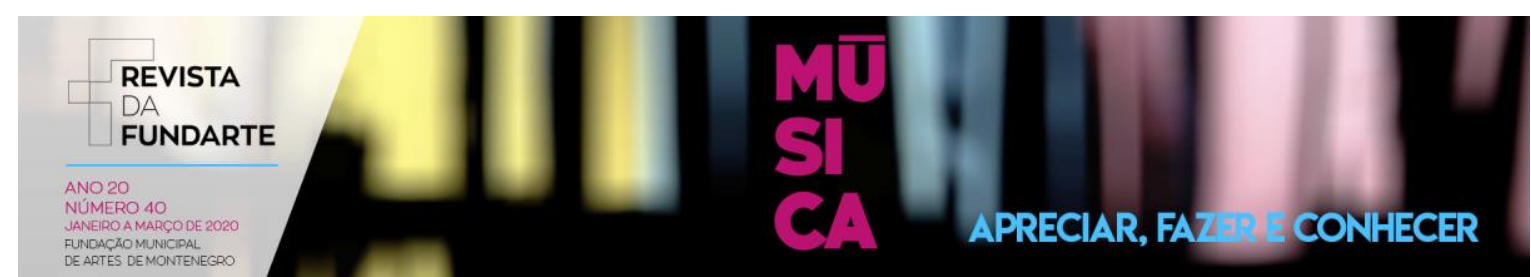

\title{
O CICLO DA ABORDAGEM CURRICULAR EM EDUCAÇÃO MUSICAL
}

Bruno Felix da Costa Almeida ${ }^{1}$

Resumo: Este artigo configura um recorte da dissertação de mestrado intitulada: "Do Texto ao Contexto, Da Imagem ao Som: Uma Proposta Histórico-Política para a Elaboração de um Currículo em Educação Musical", apresentando o Ciclo da Abordagem Curricular em Educação Musical, o qual configura uma proposta teórico-metodológica para a elaboração de um Currículo em Educação Musical. Nesse sentido, são relacionadas algumas considerações sobre o Currículo em Música e a Abordagem do Ciclo de Políticas. Contudo, entende-se que as Etapas propostas pelo estudo à elaboração de um Currículo em Educação Musical poderão ser incitadas, modificadas, dentre outros aspectos, a partir do contexto a qual será viabilizada.

Palavras-chave: Currículo em Música; Abordagem do Ciclo de Políticas; Ciclo da Abordagem Curricular em Educação Musical.

\section{THE CYCLE OF THE CURRICULAR APPROACH IN MUSIC EDUCATION}

\begin{abstract}
This article configures a section of the master's thesis entitled: "Do Texto ao Contexto, Da Imagem ao Som: Uma Proposta Histórico-Política para a Elaboração de um Currículo em Educação Musical", presenting the Cycle of the Curricular Approach in Musical Education, which configures a theoretical-methodological proposal for the elaboration of a Curriculum in Music Education. In this sense, some considerations about the Music Curriculum and the Policy Cycle Approach are related. However, it is understood that the Steps proposed by the study to the preparation of a Curriculum in Music Education may be incited, modified, among other aspects, from the context to which it will be made possible.
\end{abstract}

Keywords: Curriculum in Music; Policy Cycle Approach; Cycle of the Curricular Approach in Music Education.

\section{Introdução}

O Ciclo da Abordagem Curricular em Educação Musical configura uma proposta teórico-metodológica para a elaboração de um Currículo em Educação Musical, a qual emergiu a partir da investigação desenvolvida junto ao Programa de Pós-graduação Mestrado Profissional em Educação, da Universidade Estadual do Rio Grande do Sul (UERGS), que deu origem à dissertação de mestrado intitulada:

\footnotetext{
1 Mestre em Educação, Especialista em Educação Musical e Licenciado em Música, pela Universidade Estadual do Rio Grande do Sul; Especialista Ensino de Arte, pela Universidade Cidade de São Paulo; Bacharel em Música - Habilitação em Piano, pela Universidade Cruzeiro do Sul. Formado em Piano, pela Escola Municipal de Música - Departamento do Theatro Municipal de São Paulo; e em Teclado, pelo Conservatório Musical In'Concert. Atualmente desenvolve pesquisas nos campos da Educação, Educação Musical, Psicologia da Aprendizagem e Políticas Educacionais. Tem experiência na área de artes com ênfase em música/ensino/educação e interpretação.
}

ALMEIDA, Bruno Felix da Costa Almeida. .O ciclo da abordagem curricular em educação musical. Revista da FUNDARTE. Montenegro, p.87-109, ano 20, oㅡ 40, janeiro/março de 2019. Disponível em: http://.seer.fundarte.rs.gov.br/index.php/RevistadaFundarte/index> 31 de março de 2020 


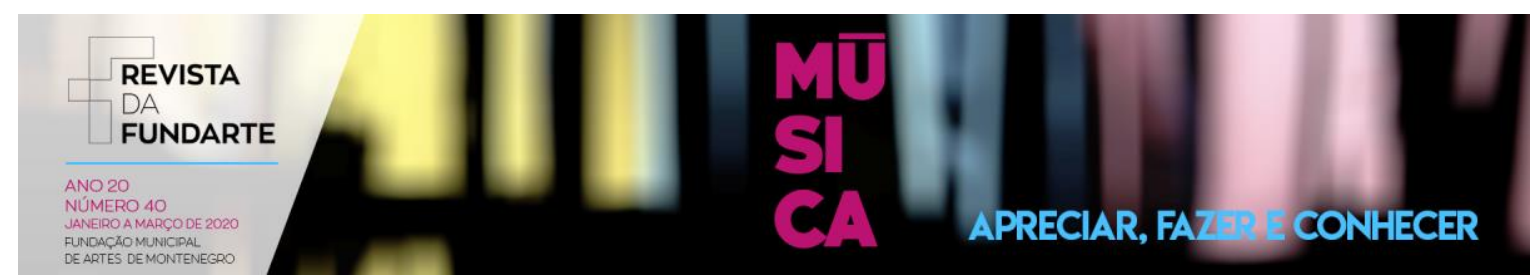

"Do Texto ao Contexto, Da Imagem ao Som: Uma Proposta Histórico-Política para a Elaboração de um Currículo em Educação Musical".

A pesquisa realizada teve como contexto de investigação o Colégio Gaspar Silveira Martins, localizado na cidade de Venâncio Aires - Rio Grande do Sul, o que oportunizou o surgimento de algumas indagações, as quais nortearam a sua realização, quais sejam: Como a Educação Musical pode ser proposta, enquanto currículo e complemento curricular, no contexto sócio-pedagógico do Colégio Gaspar Silveira Martins? Como a historicidade da implementação da Educação Musical, do Colégio Gaspar Silveira Martins, pode contribuir para a construção de uma proposta Curricular em Música? Como a articulação entre a história institucional e as políticas públicas em educação podem auxiliar na proposição de um Currículo em Música para o Colégio Gaspar Silveira Martins?

A investigação, portanto, objetivou a elaboração de uma proposta curricular em Educação Musical para o Colégio Gaspar Silveira Martins, com ênfase em seu contexto histórico-social e nas Políticas Públicas para a operacionalização do ensino da Música na Educação Básica.

No entanto, o escopo desse artigo se configura na apresentação de um recorte dessa investigação, preocupando-se em compartilhar a teoria desenvolvida para a elaboração da proposição do Currículo em Educação Musical, considerando a instituição selecionada enquanto lócus de pesquisa.

Reflexões sobre os aspectos histórico-institucionais, voltados à Educação Musical do Colégio Gaspar Silveira Martins, e as perspectivas atuais em Educação e Educação Musical, contribuíram à importância de se pensar e propor um Currículo em Educação Musical que pudesse respaldar, bem como nortear o trabalho pedagógico-musical dos docentes em música da instituição, ou seja, que pudesse fortalecer às relações entre o Colégio, os alunos e a comunidade local, visto que estas podem se tornar cada vez mais integradas, a partir de ações educativas e culturais.

Nesse sentido, pensar o Currículo em Educação Musical tornou-se um desafio para as necessidades humanas, desintegrando e integrando conhecimentos

ALMEIDA, Bruno Felix da Costa Almeida. .O ciclo da abordagem curricular em educação musical. Revista da FUNDARTE. Montenegro, p.87-109, ano 20, no 40, janeiro/março de 2019. Disponível em: http://.seer.fundarte.rs.gov.br/index.php/RevistadaFundarte/index> 31 de março de 2020 


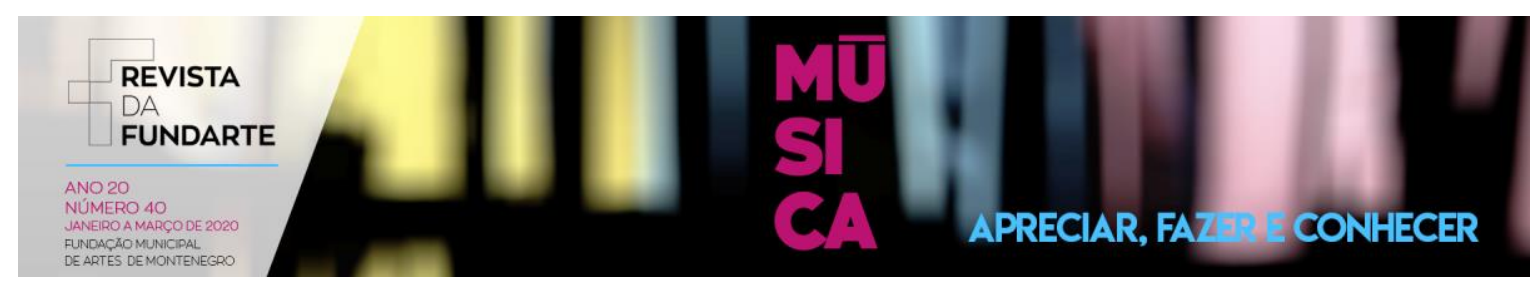

em prol da constituição de novos saberes que possam abarcar a realidade de contextos educativo-institucionais, além de, também, contribuir para a área da Educação Musical a partir da interlocução de conhecimentos das ciências sociais à transformação e consolidação do que é a Educação Musical na atualidade e como ela pode se constituir diante dos desafios enfrentados nos diferentes tempos e espaços das escolas de Educação Básica brasileiras, considerando a união entre a Educação, a Filosofia da Educação, as Políticas em Educação e em Educação Musical.

\section{Currículo: Concepções e Estratégias de Elaboração}

Ao se dispor a refletir sobre como elaborar, constituir, propor e, principalmente, desenvolver na ação (implementação/operacionalização) a proposição de um currículo em Educação Musical para a Educação Básica, foi necessário buscar resposta(s) sobre a seguinte proposição: "Currículo: como se define?".

Para tanto, a articulação entre os conceitos curriculares que transitam entre as áreas da Educação e Educação Musical foram transformados em subsídio para a exposição analítico-conceitual do Currículo em Educação Musical que se objetivou constituir, com ênfase nos estudos desenvolvidos por Sacristán (2017), McKernan (2009) e Silva (2001), em se tratando de relações curriculares à área da Educação; e, em específico, no campo da Educação Musical, apropriou-se da concepção de currículo a partir dos estudos empreendidos pelos autores Abeles, Hoffer e Klotman (1984) - sobre a qual se relaciona neste escopo de modo mais amplo.

Frente às articulações conceituais propostas salienta-se as concepções de "Currículo" para os autores selecionados. A Figura 1 abaixo relaciona as definições observadas e selecionadas a partir da literatura supracitada.

ALMEIDA, Bruno Felix da Costa Almeida. .O ciclo da abordagem curricular em educação musical. Revista da FUNDARTE. Montenegro, p.87-109, ano 20, no 40, janeiro/março de 2019. Disponível em: http://.seer.fundarte.rs.gov.br/index.php/RevistadaFundarte/index> 31 de março de 2020 


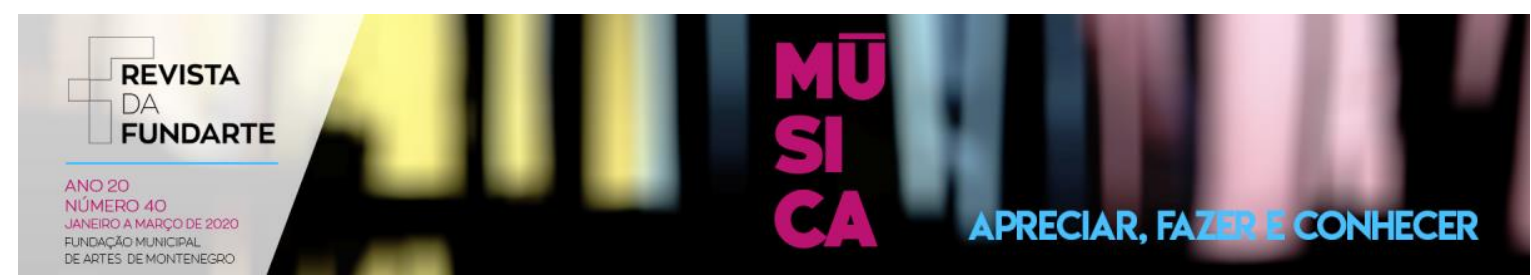

\begin{tabular}{|l|l|}
\hline $\begin{array}{l}\text { Sacristán: "O currículo, em seu conteúdo e nas formas pelas quais nos apresenta e se } \\
\text { apresenta aos professores e aos alunos, é uma opção historicamente configurada, que se } \\
\text { sedimentou dentro de uma determinada trama cultural, política, social e escolar; está } \\
\text { carregado de valores e pressupostos que é preciso decifrar". (SACRISTÁN, 2017,p. 17). }\end{array}$ \\
$\begin{array}{l}\text { McKernan: "Um currículo é a proposta de política educacional em oferta feita por uma } \\
\text { escola ou faculdade e se compõe de conhecimento, valores, habilidades e outras capacidades } \\
\text { que foram intencionalmente planejadas". (McKERNAN, 2009, p. 23). }\end{array}$ \\
$\begin{array}{l}\text { Silva: O currículo pode ser definido como: "1) uma prática de significação; 2) uma prática } \\
\text { produtiva; 3) uma relação social; 4) uma relação de poder; 5) uma prática que produz } \\
\text { identidades sociais". (SILVA, 2001,p. 17). }\end{array}$ \\
$\begin{array}{l}\text { Abeles, Hoffer e Klotman: O currículo é um conjunto de experiências planejadas e } \\
\text { incorporadas a partir de: 1) diferentes pontos de vistas; 2) fatores qualitativos; 3) aspectos } \\
\text { filosóficos. (ABELES, HOFFER, KLOTMAN, 1984). }\end{array}$ \\
\hline
\end{tabular}

Figura 1 - Algumas Definições de Currículo. Fonte: Elaboração nossa, a partir de Sacristán (2017), McKernan (2009), Silva (2001) e Abeles, Hoffer e Klotman (1984).

Direcionando a reflexão aos meandros educativo-musicais, propor um currículo em música é um desafio importante. Abeles, Hoffer e Klotman (1985) denotam que a definição sobre "o que" ensinar é um ponto preponderante para os educadores musicais, ao passo que consideram que "o tópico do currículo [...] é uma parte essencial e significativa do processo de educação" (p. 265).

Os autores apontam que alguns profissionais "encaram um currículo como uma área de atividades em andamento, que estão acontecendo atualmente dentro da sala de aula, ao invés de encará-lo como um plano de estudo estático, já estabelecido" (ABELES; HOFFER; KLOTMAN, 1985, p. 265). Tal perspectiva é considerada enquanto "currículo operacional", explicam Abeles, Hoffer e Klotman (1985).

Há, também, o currículo "ideal” - "esse 'ideal' geralmente é uma abstração que pode ou não existir" - deste modo, pode se desenvolver "sob condições escolares e é resultado do que teóricos e filósofos acreditam que o plano de estudo exemplar deveria ser" (ABELES; HOFFER; KLOTMAN, 1985, p. 266).

Outro modelo de currículo relacionado pelos autores consiste no chamado currículo "experiencial", baseado nas experiências contextuais da sala de aula, ao

ALMEIDA, Bruno Felix da Costa Almeida. .O ciclo da abordagem curricular em educação musical. Revista da FUNDARTE. Montenegro, p.87-109, ano 20, no 40, janeiro/março de 2019. Disponível em: http://.seer.fundarte.rs.gov.br/index.php/RevistadaFundarte/index> 31 de março de 2020 


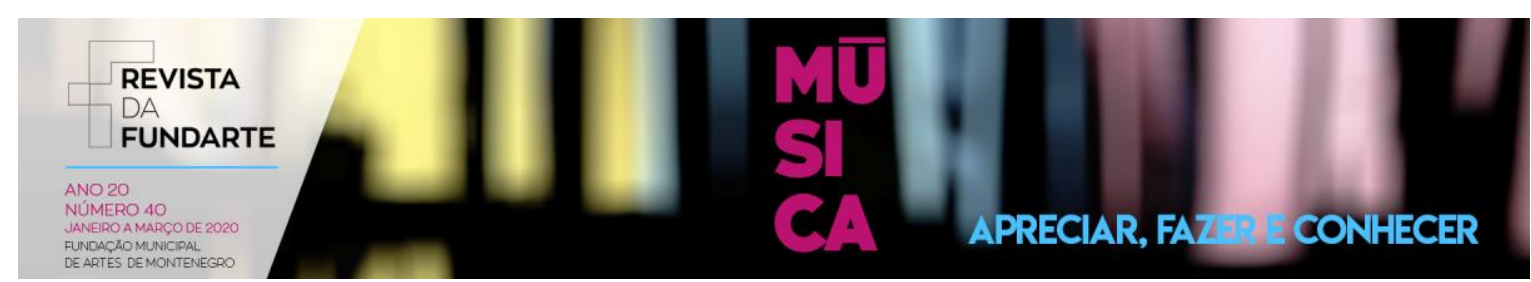

passo que "essa perspectiva é similar à posição tomada pelos que apoiam a definição ‘operacional'” (ABELES; HOFFER; KLOTMAN, 1985, p. 266).

A relação principal atrelada às concepções de currículo em música apontada pelos autores corresponde à abordagem formalizada por Klein e colaboradores, a qual é relacionada na Figura 2. No esquema apresentado relacionam-se: A) Perspectivas do Currículo, B) Variações Curriculares e C) Fatores Qualitativos. A partir desta visão curricular os autores esclarecem que:

Uma composição dessas visões talvez defina o currículo como um conjunto de experiências planejadas que são incorporadas em todas as experiências supracitadas. Essa natureza particular exige que a forma como estas experiências sejam apresentadas variem de acordo com os alunos, assim como as condições que mudam dentro de uma escola diariamente. Essas experiências são afetadas pelos fatores qualitativos, assim como pela percepção que alguém tem do currículo. $E$ isso é refletido na descrição individual. $O$ currículo é influenciado por quem tem o poder de tomar decisões. (ABELES; HOFFER; KLOTMAN, 1985, p. 266-268).

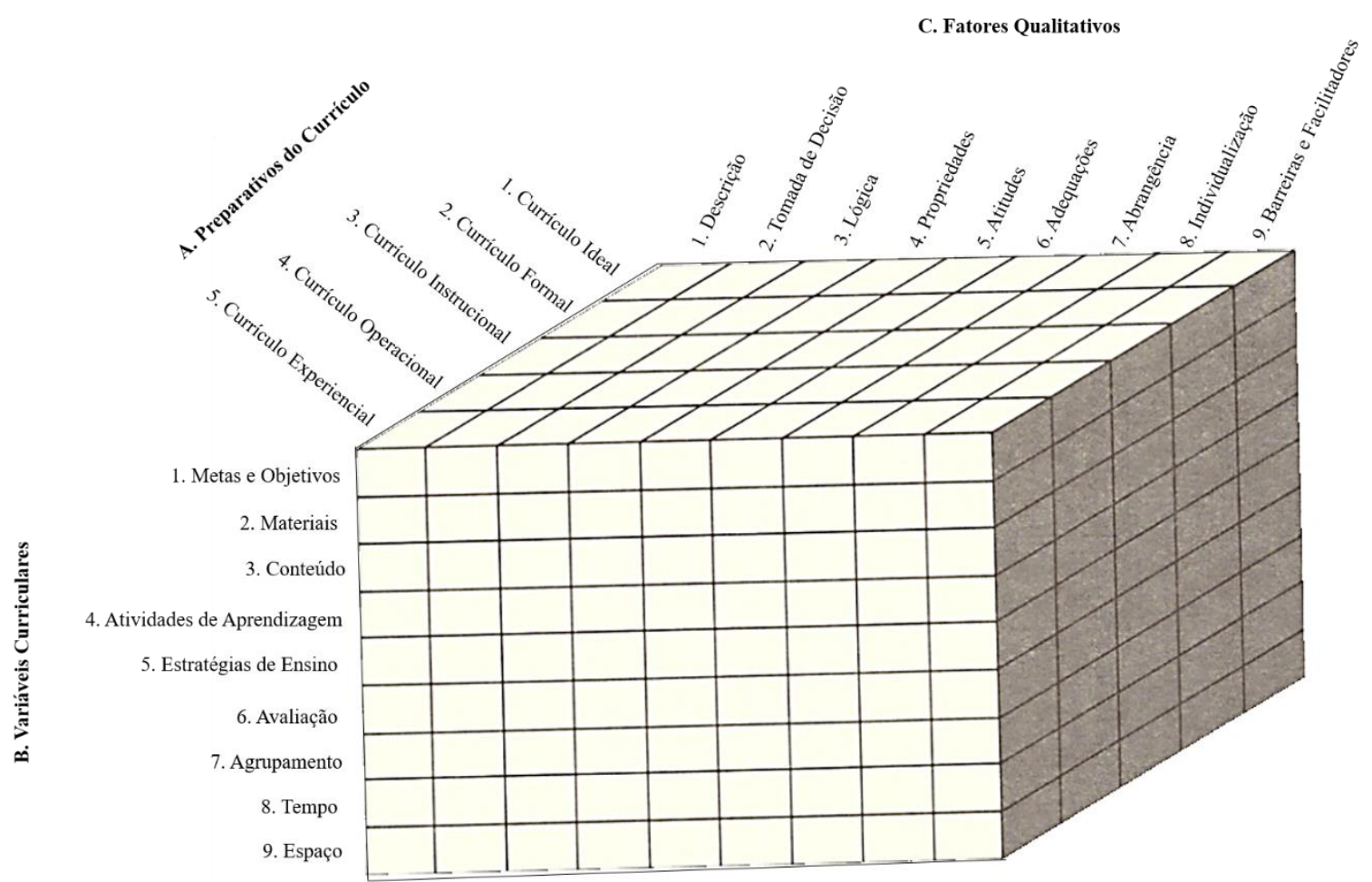

Figura 2 - Teoria do Currículo. Fonte: Elaboração nossa, a partir de Abeles, Hoffer e Klotman (1985, p. 267). FIGURE 10.1. Curriculum conceptual framework for data collection and analysis: a study os schooling. Souce: M. Frances Klein, Kenneth A. Tye, and Joyce E. Wright, "A Study of Schooling:

Curriculum." Reprinted from Phi Delta Kappan. December 1979.

ALMEIDA, Bruno Felix da Costa Almeida. .O ciclo da abordagem curricular em educação musical. Revista da FUNDARTE. Montenegro, p.87-109, ano 20, no 40, janeiro/março de 2019. Disponível em: http://.seer.fundarte.rs.gov.br/index.php/RevistadaFundarte/index> 31 de março de 2020 


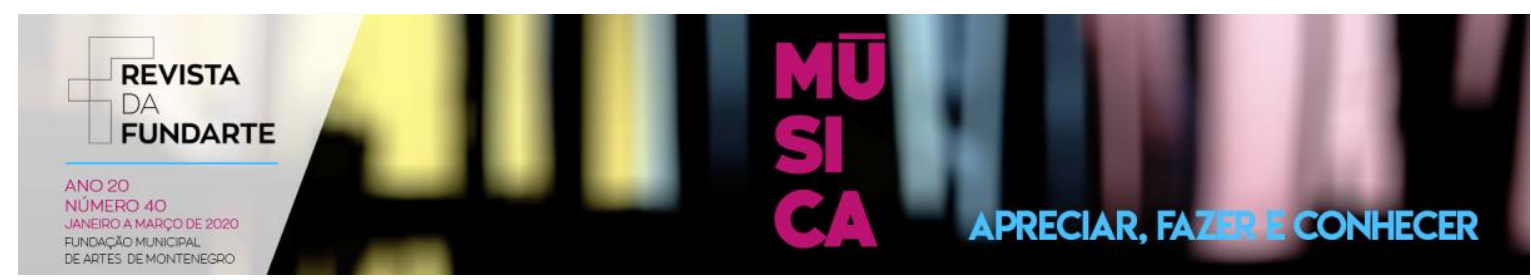

Abeles, Hoffer e Klotman (1985) corroboram explicando que "as atitudes dos professores e especialistas de currículos, administradores e do público [...] terão um impacto na qualidade do programa sendo ofertado. Essas considerações estão em proporção direta com o que de fato constitui um currículo, como é ofertado na escola" (p. 268).

Ao analisar a Figura 2 é possível relacionar a profundidade de relações possíveis na elaboração de um Currículo em Educação Musical. No item "A" vislumbra-se a seleção da perspectiva curricular a qual se pretende empreender/desenvolver, quer seja através da proposição de um modelo curricular ideal, formal, instrucional, operacional ou experiencial. Entende-se que a partir desta seleção seja possível adequar as variáveis, ao passo que o conglomerado das opções em "B" poderão favorecer a constituição da proposta curricular: metas e objetivos, materiais, conteúdo, atividade de aprendizagem, estratégias de ensino, avaliação, agrupamento, tempo e espaço. Por fim, considerando-se " $\mathrm{C}$ ", com os fatores qualitativos: descrição, tomada de decisão, lógica, propriedades, atitudes, adequações, abrangência, individualização e barreiras e facilitadores, torna-se possível aprofundar as relações de aproveitamento do currículo.

A articulação entre o que se entende por currículo nos campos da Educação e da Educação Musical torna-se balizadora para a constituição da proposição do Currículo em Educação Musical. A definição de currículo, portanto, está para as escolhas culturais e sociais, coletivas e individuais, institucionais e políticas, dentre outras, em que se possa apropriar-se para contemplar, na práxis, o ensino da música na Educação Básica.

As metas, os objetivos, os conteúdos e os materiais didáticos, por sua vez, podem se constituir como alguns dos elementos que, atrelados aos fatores qualitativos, poderão subsidiar as relações administrativas, docentes e socioculturais no campo de ação. Assim como as definições de tempo, espaço, perfil institucional e perfil dos sujeitos imbricados na ação educativa poderão ser levados em consideração para esta proposição.

ALMEIDA, Bruno Felix da Costa Almeida. .O ciclo da abordagem curricular em educação musical. Revista da FUNDARTE. Montenegro, p.87-109, ano 20, no 40, janeiro/março de 2019. Disponível em: http://.seer.fundarte.rs.gov.br/index.php/RevistadaFundarte/index> 31 de março de 2020 


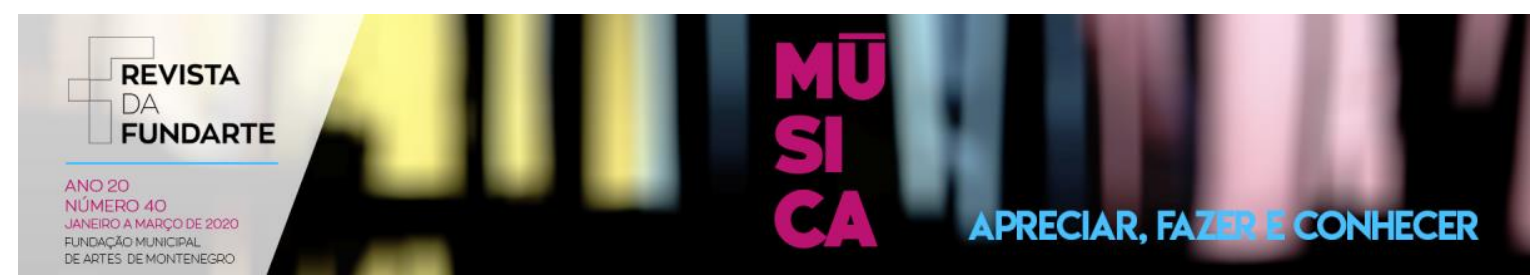

O conhecimento histórico e social do contexto também poderá fortalecer as expectativas constitutivas ao que se espera de uma concepção de Educação Musical com ênfases macrocontextuais, enquanto políticas públicas que alicerçam as ações de ensino e aprendizagem na Educação Básica, e microcontextuais, percebendo os impactos de ações externas ao contexto institucional e de sala de aula.

A política, então, torna-se a pauta da interação entre o global, o local e, principalmente, o estritamente particular - a relação professor e aluno em ambientes de aprendizagem de Educação Musical - no contexto da Educação Básica.

\section{A Abordagem do Ciclo de Políticas}

A apropriação da Abordagem do Ciclo de Políticas - a qual não se constitui um método, mas "uma maneira de pesquisar e teorizar as políticas", conforme explica Ball em entrevista aos pesquisadores Mainardes e Marcondes (2009, p. 305) - "é uma maneira de pensar as políticas e saber como elas são 'feitas', usando alguns conceitos que são diferentes" (MAINARDES; MARCONDES, 2009, p. 305). Nesse sentido, Ball explica sua rejeição sobre o entendimento de que políticas possam ser "implementadas", sugerindo-a enquanto um processo linear em direção à prática, ao passo que considera a política uma decifração entre o texto e a ação, enquanto desafio relacionados ao fazer, ao processo de atuação e efetivação política na prática e através dela (MAINARDES; MARCONDES, 2009).

Em se tratando do contexto brasileiro, "a reflexão sobre tal abordagem é bastante útil”, explica Mainardes (2006, p. 48), com vistas ao desenvolvimento e fortalecimento de pesquisas deste cunho no cenário nacional. O autor, ao traçar a trajetória que constituiu a proposição da Abordagem do Ciclo de Políticas, relaciona que inicialmente a proposição de Ball e Bowe relacionava-se à caracterização do processo político em um ciclo contínuo "constituídos por três facetas ou arenas políticas: a política proposta, a política de fato e a política em uso" (MAINARDES, 2006, p. 49).

ALMEIDA, Bruno Felix da Costa Almeida. .O ciclo da abordagem curricular em educação musical. Revista da FUNDARTE. Montenegro, p.87-109, ano 20, no 40, janeiro/março de 2019. Disponível em: http://.seer.fundarte.rs.gov.br/index.php/RevistadaFundarte/index> 31 de março de 2020 


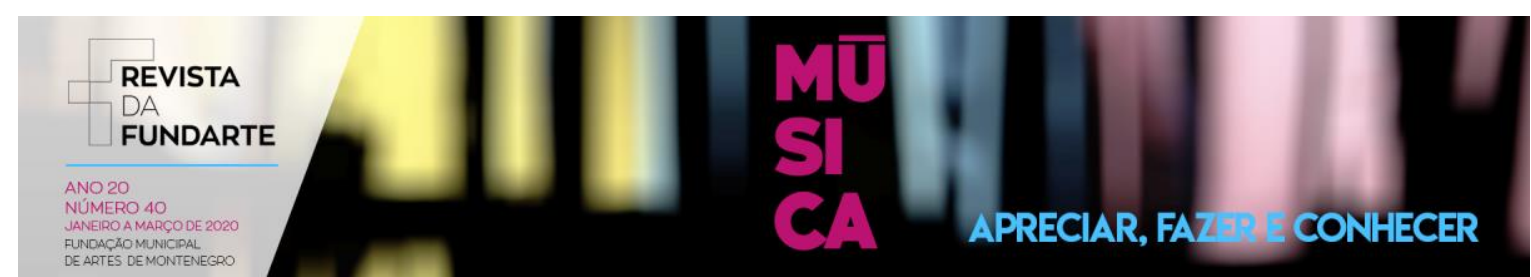

A primeira faceta, a "política proposta", referia-se à política oficial, relacionada com as intenções não somente do governo e de seus assessores, departamento educativos e burocratas encarregados de "implementar" políticas, mas também intenções das escolas, autoridades locais e outras arenas onde as políticas emergem. A "política de fato" constituía-se pelos textos políticos e textos legislativos que dão forma à política proposta e são as bases iniciais para que as políticas sejam colocadas em prática. Por último, a "política em uso" referia-se aos discursos e às práticas institucionais que emergem do processo de implementação das políticas pelos profissionais que atuam no nível da prática. (MAINARDES, 2006, p. 49).

O modelo de política relacionado é logo depois rompido por Ball e Bowe, por apresentarem uma rigidez não intencionada. Portanto, uma nova e aprimorada versão foi estabelecida a partir da publicação de 1992, em parceria entre Bowe, Ball e Gold, compreendendo que o Estado e a Escola são diferentemente capacitados no decorrer do tempo, ao processo político.

Nesse sentido, em um ciclo contínuo, os autores propuseram três conceitos inter-relacionados em uma dimensão atemporal ou não sequencial, ou seja, não se constituem uma linearidade, mas sim um ciclo de acontecimentos que podem até se sobrepor, quais sejam: o Contexto da Influência, o Contexto da Produção do Texto Político e o Contexto da Prática.

O primeiro contexto a ser relacionado pelos autores é o Contexto da Influência, no qual a política pública normalmente é iniciada. A política, enquanto discurso, é constituída entre as partes interessadas em influenciar a definição e fins sociais à educação. Bowe, Ball e Gold (1992) esclarecem que é neste momento que "os conceitos-chave da política são estabelecidos" (p. 19), projetam-se reivindicações de influência em arenas de ação pública por intermédio midiático, além de outras áreas mais formais, tais como "comissões, organismos nacionais, representantes de grupos que podem ser locais para a articulação de influência" (BOWE; BALL; GOLD, 1992, p. 20). São atuantes neste contexto redes sociais vinculadas ou não a partidos políticos governamentais ou pertencentes a processos legislativos.

ALMEIDA, Bruno Felix da Costa Almeida. .O ciclo da abordagem curricular em educação musical. Revista da FUNDARTE. Montenegro, p.87-109, ano 20, o 40, janeiro/março de 2019. Disponível em: http://.seer.fundarte.rs.gov.br/index.php/RevistadaFundarte/index> 31 de março de 2020 


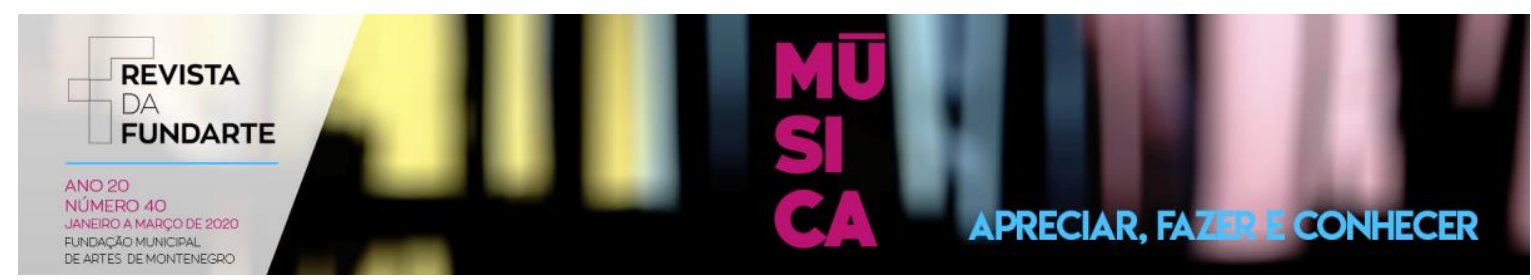

O "empréstimo de políticas" oportunizado pela globalização, que, quando articuladas em detrimento de adequações à alguma localidade específica, Ball a denomina de "bricolagem". A bricolagem, portanto, configura-se em "um constante processo de empréstimo e cópia de fragmentos e partes de ideias de outros contextos, de uso e melhoria das abordagens locais já tentadas e testadas" (BALL, 2011, p. 102). Além destas ideias, Ball (2001, p. 102) complementa que a apropriação de "teorias canibalizadoras, de investigação, de adoção de tendências e modas e, por vezes, de investimento em tudo aquilo que possa vir a funcionar", também podem ser articulados em um processo de bricolagem.

Para Ball (2011), "as políticas normalmente não dizem o que fazer, elas criam circunstâncias nas quais o espectro de opções disponíveis sobre o que fazer é reduzido ou modificado ou em que metas particulares ou efeitos são estabelecidos" (p. 46-47). Diante das relações de influência, a qual Bowe, Ball e Gold (1992) esclarecem, também, enquanto relações "simbiótica", emerge o segundo contexto, o Contexto de Produção do Texto Político. O apelo direcionado aos textos políticos incide na razão, bom senso, política popular, enquanto forma de registro representativo da própria política, podendo assumir diversas formas representativas, tais como os textos jurídicos e documentos políticos. No entanto, os textos políticos são passíveis de interpretações distintas, sua leitura e interpretação estão sujeitas à "luz" dos conhecimentos de mundo daqueles que a relacionam e a empregam na prática (BOWE; BALL; GOLD, 1992). Constituem-se "de múltiplas influências e agendas e sua formulação envolve intenções e negociação dentro do Estado e dentro do processo de formulação da política" (MAINARDES, 2006, p. 53).

As intervenções textuais acarretam "restrições e possibilidades" que, por sua vez, remetem a consequências "reais", e direcionam-se ao terceiro contexto, o Contexto da Prática (BOWE; BALL; GOLD, 1992). Nesse sentido, "o processo de traduzir políticas em práticas é extremamente complexo; é uma alternação entre modalidades. A modalidade primária é a textual, pois as políticas são escritas, enquanto que a prática é ação, inclui o fazer coisas”, esclarece Ball em entrevista para Mainardes e Marcondes (2009, p. 305).

ALMEIDA, Bruno Felix da Costa Almeida. .O ciclo da abordagem curricular em educação musical. Revista da FUNDARTE. Montenegro, p.87-109, ano 20, o 40, janeiro/março de 2019. Disponível em: http://.seer.fundarte.rs.gov.br/index.php/RevistadaFundarte/index> 31 de março de 2020 


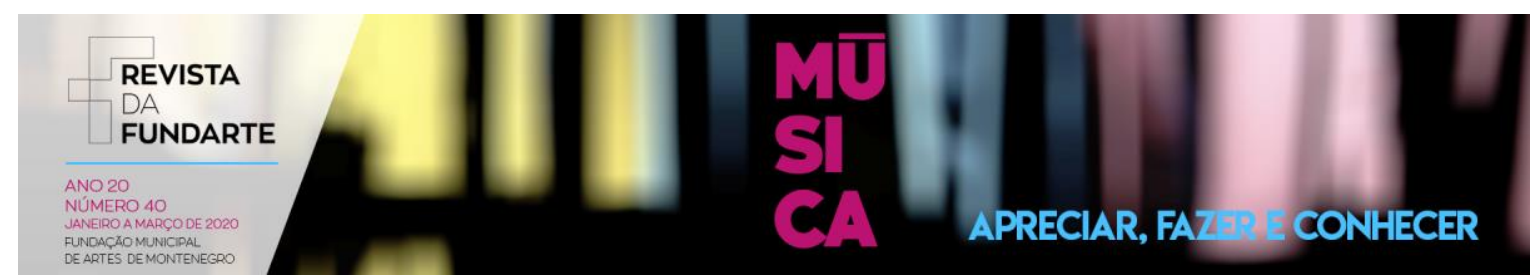

Ball também relaciona a política enquanto discurso, que "estabelece limites sobre o que é permitido pensar e tem o efeito de discutir 'vozes', uma vez que somente algumas vozes serão ouvidas como legítimas e investidas de autoridade" (MAINARDES, 2006, p. 54). A relação entre política enquanto texto e a política como discurso são complementares, ao passo que a primeira "enfatiza o controle que está nas mãos dos leitores", e a última "enfatiza os limites impostos pelo próprio discurso" (MAINARDES, 2006, p. 54).

O Contexto da Prática polariza a inviabilidade de controle daquele que escreve o texto político, pois "os escritores de política não podem controlar os significados de seus textos", esclarecem Bowe, Ball e Gold (1992, p. 22). Como consequência, em se tratando do contexto escolar, a intepretação e reinterpretação de políticas educativas possibilita que professores e profissionais exerçam efetiva atuação e participação sobre o processo de sua ação (MAINARDES, 2006).

Na entrevista concedida a Mainardes e Marcondes (2009), Ball explica que "a prática é composta de muito mais do que a soma de uma gama de políticas e é tipicamente investida de valores locais e pessoais e, como tal envolve a resolução de, ou luta com, expectativas e requisitos contraditórios - acordos e ajustes secundários fazem-se necessários" (p. 305).

Nesta relação, Ball considera os conhecimentos dos professores como possibilidade de influência para a interpretação do texto, ou seja, os docentes, em suas interpretações e reinterpretações, podem exprimir a presença de suas histórias de vida, de suas histórias relacionadas à escola, bem como ao currículo escolar (MAINARDES; MARCONDES, 2009).

Em 1994, com a publicação de Education reform: $A$ critical and post-structural approch, Ball amplia a Abordagem do Ciclo de Políticas inserindo mais dois contextos: o Contexto dos Resultados (efeitos) e o Contexto da Estratégia Política, considerados de fundamental importância para as análises político-educativas: "A relação entre os contextos - de influência, de produção do texto político, da prática, de resultados e de estratégias - é fundamental para a percepção do modelo como ciclo contínuo e não hierarquizado", esclarecem Lopes e Macedo (2011, p. 156). Tal Revista da FUNDARTE. Montenegro, p.87-109, ano 20, o 40, janeiro/março de 2019. Disponível em: http://.seer.fundarte.rs.gov.br/index.php/RevistadaFundarte/index> 31 de março de 2020 


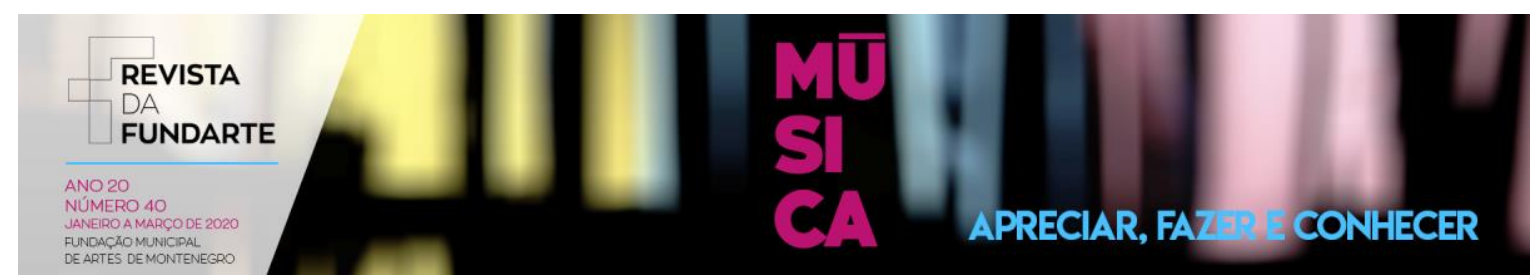

ampliação também possibilitou outras estratégias de análises, compreendendo “aninhamentos". Segundo Ball, considerando-se o contexto da prática, seria possível inserir o Contexto de Influência e o Contexto de Produção de Texto, ao passo que o Contexto da Influência pode estabelecer relações no Contexto da Prática, de modo que "assim, podem existir disputas ou versões em competições dentro do contexto da prática, em diferentes interpretações de interpretações", além de possibilitar a existência - complementa Ball em entrevista - de "um contexto de produção de texto dentro do contexto de prática, na medida em que materiais práticos são produzidos para utilização dentro da atuação" (MAINARDES; MARCONDES, 2009, p. 307-308).

Ao abordar o Contexto dos Efeitos - que pode variar de acordo com o Contexto da Prática Política - Ball (1994) esclarece que este contexto implica, efetivamente, efeitos e não resultados, tornando seus aspectos evidentes quando as respostas obtidas são relacionadas a partir de categorias (gerais e específicas). A compreensão sobre os efeitos gerais da política é propiciada quando, a partir da prática, são agrupados e analisados os quadros de respostas da ação.

O autor designa que "uma negligência da visão geral é mais comum em estudos que possuem apenas um foco no qual se tenta determinar o impacto de uma política de texto", o que pode ocasionar efeitos limitados da política posta em ação (BALL, 1994, p. 24). Entretanto, os efeitos relacionados a uma política específica podem oportunizar um contexto de análise diferente: 1) "existe um perigo na idealização do passado retratando uma situação na qual os professores tinham autonomia, mas agora não possuem mais", e 2) "a generalização não englobara a experiência de todos os tipos de professores em todos os tipos de situação" (BALL, 1994, p. 25).

Conforme corrobora Mainardes (2009) "isso sugere ainda a necessidade de que as políticas locais ou as amostras de pesquisas sejam apenas como ponto de partida para a análise de questões mais amplas da política” (p. 55). O autor complementa exemplificando que no primeiro item pode se relacionar a "análise das mudanças e do impacto em/sobre o currículo, pedagogia, avaliação e organização",

ALMEIDA, Bruno Felix da Costa Almeida. .O ciclo da abordagem curricular em educação musical. Revista da FUNDARTE. Montenegro, p.87-109, ano 20, no 40, janeiro/março de 2019. Disponível em: http://.seer.fundarte.rs.gov.br/index.php/RevistadaFundarte/index > 31 de março de 2020 


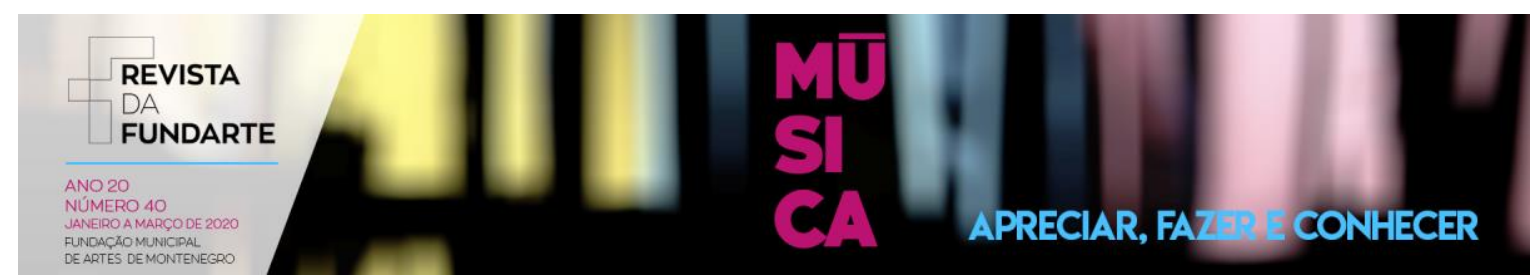

enquanto que no segundo relaciona-se as "interfaces da política com outras políticas setoriais e com o conjunto das políticas" (MAINARDES, 2009, p. 54-55).

Além das distinções apresentadas, Ball (1994) aponta que ainda há outras existentes, em se tratando do contexto dos efeitos, quais sejam: "efeitos de primeira ordem", que configuram "mudanças na prática ou na estrutura (nas quais são evidentes em lugares particulares e no sistema como um todo)" e os "efeitos de segunda ordem", em que consistem em "impactos das mudanças nos padrões de acesso, oportunidade e justiça social" (p. 25-26).

Por sua vez, o Contexto de Estratégia Política incide sobre o desenvolvimento das atividades sociais e políticas, fundamentais para analisar as relações de desigualdades (reproduzidas ou criadas) na política (BALL, 1994).

\begin{abstract}
Cada contexto consiste em um número de arenas de ação - algumas privadas e algumas públicas. Cada contexto envolve conflitos e consensos entre os pares. Eles são informalmente agrupados e não existe uma simples direção entre eles. Mas, em termos teóricos e práticos, esse modelo exige dois "contextos" para torná-lo por completo. O primeiro consiste em considerar a relação entre os efeitos de primeira ordem (prática) e os efeitos de segunda ordem; isso é, o contexto de resultados. Aqui a preocupação analítica envolve as questões de justiça, igualdade e liberdade. Políticas são analisadas em termos de seus impactos e interações com desigualdades existentes e forma de injustiça. (BALL, 1994, p. 26).
\end{abstract}

Em entrevista a Mainardes e Marcondes (2009), Ball explica que pensou os cinco contextos articulados em conjunto. Assim, sobre os dois últimos contextos elaborados, Contexto dos Resultados ou Efeitos e o Contexto de Estratégia Política, Ball esclarece que "o contexto da ação política, na realidade, pertence ao contexto de influência, porque é parte do ciclo do processo através do qual as políticas são mudadas, ou podem ser mudadas ou, pelo menos, o pensamento sobre as políticas muda ou pode ser mudado"; deste modo, complementa o autor, "o pensar sobre as políticas e o discurso das políticas podem ser mudados pela ação política [...], podem ser submetidos e integrados ao contexto da influência" (p. 306).

A apropriação da Abordagem do Ciclo de Políticas, por parte de investigadores brasileiros, se reflete no cenário de pesquisas com ênfase na relação teórico-referencial, de acordo com a análise desenvolvida por Lopes e Macedo ALMEIDA, Bruno Felix da Costa Almeida. .O ciclo da abordagem curricular em educação musical. Revista da FUNDARTE. Montenegro, p.87-109, ano 20, o 40, janeiro/março de 2019. Disponível em: http://.seer.fundarte.rs.gov.br/index.php/RevistadaFundarte/index> 31 de março de 2020 


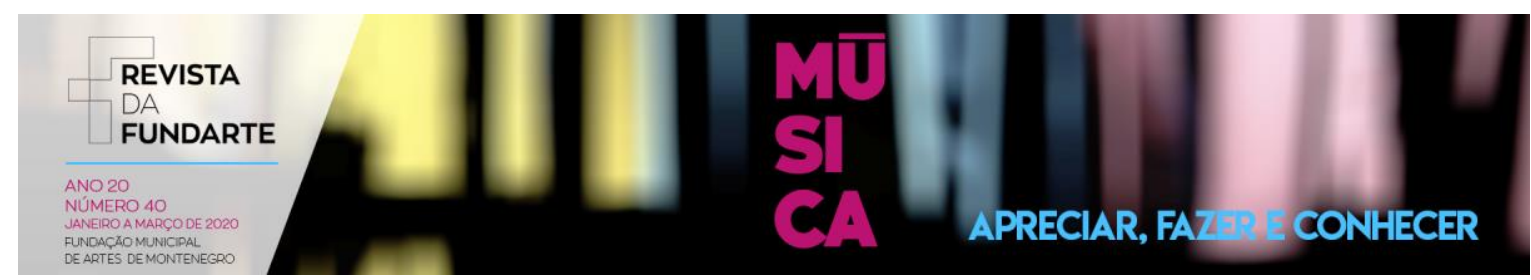

(2009), a qual as autoras relacionam o panorama das pesquisas realizadas, emergindo a consideração de que as investigações desenvolvidas reforçam "a hipótese proposta pelo ciclo de políticas de Ball, no sentido de que as comunidades disciplinares contribuem para a recontextualização de textos e discursos das propostas curriculares" (p. 268).

De acordo com Ball (2011), "A 'abordagem da trajetória' [política] capta as formas pelas quais as políticas evoluem, se modificam e decaem ao longo do tempo e do espaço, assim como as suas incoerências" (p. 38).

Com ênfase na Abordagem do Ciclo de Políticas iniciado por Bowe, Ball e Gold (1992) que, posteriormente, foi ampliado por Ball (1994), relaciona-se a seguir a Abordagem do Ciclo de Políticas transversalizada à proposição Curricular em Música.

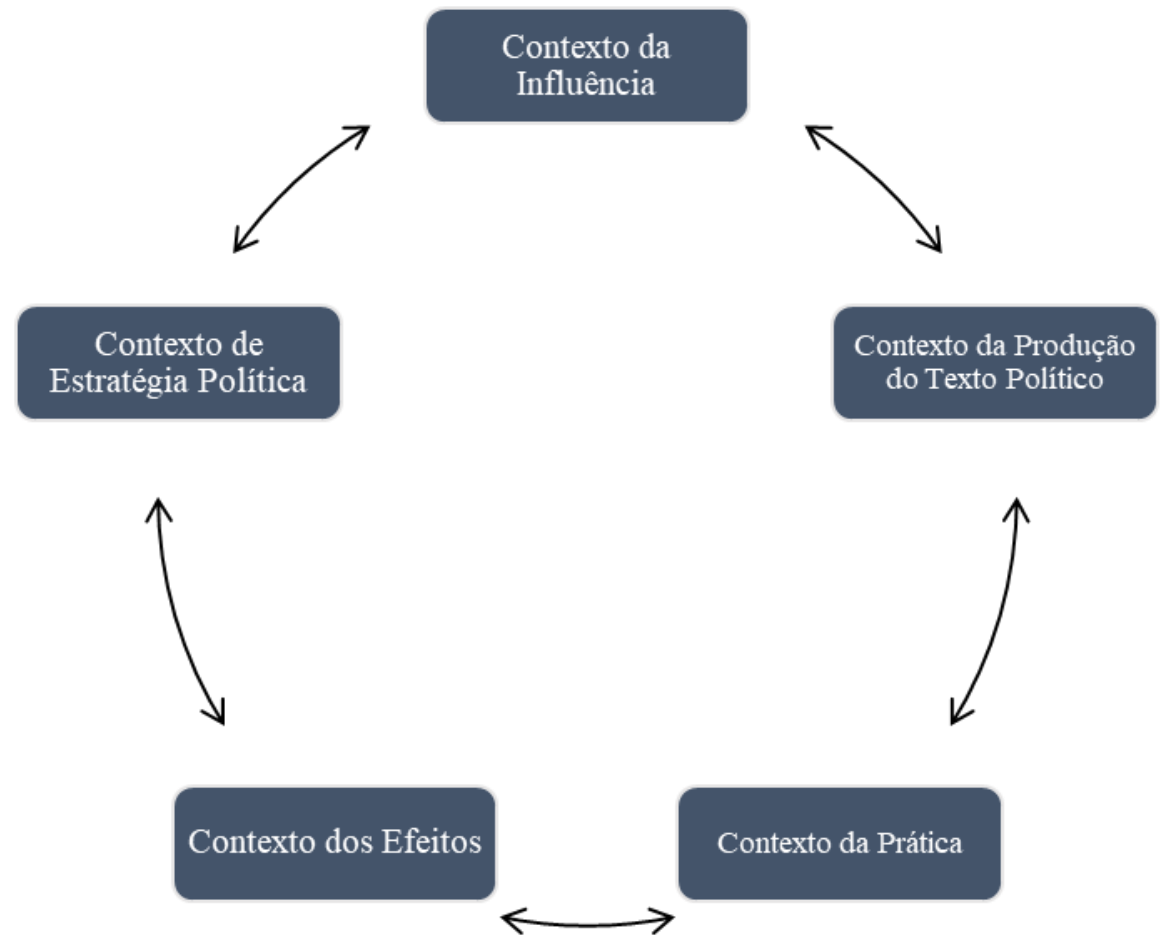

Figura 3 - Ciclo de Políticas. Fonte: Elaboração nossa, a partir de Bowe, Ball e Gold (1992) e Ball (1994).

\section{O Currículo em Educação Musical: O Conceito}

ALMEIDA, Bruno Felix da Costa Almeida. .O ciclo da abordagem curricular em educação musical. Revista da FUNDARTE. Montenegro, p.87-109, ano 20, no 40, janeiro/março de 2019. Disponível em: http://.seer.fundarte.rs.gov.br/index.php/RevistadaFundarte/index> 31 de março de 2020 


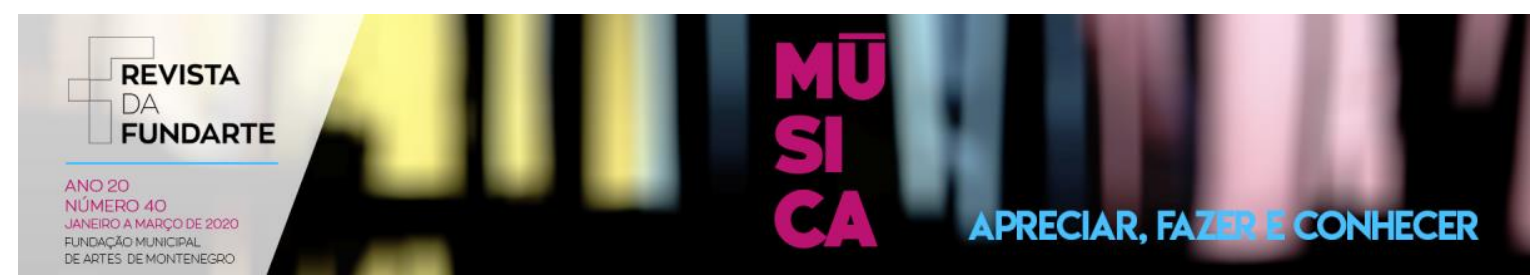

A proposta do Ciclo da Abordagem Curricular em Educação Musical emerge a partir da interação processual e correlacional entre cada uma de suas oito Etapas destinadas a elaboração curricular, com ênfase nos conhecimentos em Arte e ArteMúsica, relacionados na Base Nacional Comum Curricular (BNCC), destinada à Educação Infantil, Ensino Fundamental - Anos Iniciais e Ensino Fundamental Anos Finais (BNCC, 2017), e Ensino Médio (BNCC, 2018), na "Abordagem do Ciclo de Políticas" de Bowe, Ball e Gold (1992) e Ball (1994), e na "Teoria do Currículo" de Abeles, Hoffer e Klotman (1985).

Nesse sentido, são apresentadas as Etapas - uma reflexão teóricometodológica - ao desenvolvimento à proposição de um Currículo em Educação Musical.

A primeira Etapa, Competências Gerais em Arte, compreende os aspectos de desenvolvimento educacional relacionados às linguagens artísticas, a considerar às Artes Visuais, a Dança, o Teatro e a Música, além de outras áreas do conhecimento sociocultural globais, como a matemática, a história, a filosofia, a sociologia, a psicologia, dentre outras que possam ser/estar integradas à Arte dependendo de seus propósitos de viabilização e de seu contexto de inserção.

A segunda Etapa, Competências Educativo-musicais, abrange o explorar, o compreender, o pesquisar, o experienciar, o mobilizar, o estabelecer, o problematizar, o desenvolver e o analisar no contexto educativo-musical escolar, individual e/ou coletivo, a fim de proporcionar o conhecimento global das mais diversas manifestações educativo-musicais existentes.

A terceira Etapa, Eixos Temáticos, trata sobre a relação da aprendizagem em música às relações sociais, de autonomia de ações individuais e/ou coletivas, da construção identitária individual e coletiva, do autoconhecimento corporal, do conhecimento e reconhecimento dos elementos artísticos, da oralidade, do letramento, do conhecimento de mundo, do conhecimento na articulação da artemúsica(s) com as diferentes áreas do conhecimento.

ALMEIDA, Bruno Felix da Costa Almeida. .O ciclo da abordagem curricular em educação musical. Revista da FUNDARTE. Montenegro, p.87-109, ano 20, o 40, janeiro/março de 2019. Disponível em: http://.seer.fundarte.rs.gov.br/index.php/RevistadaFundarte/index> 31 de março de 2020 


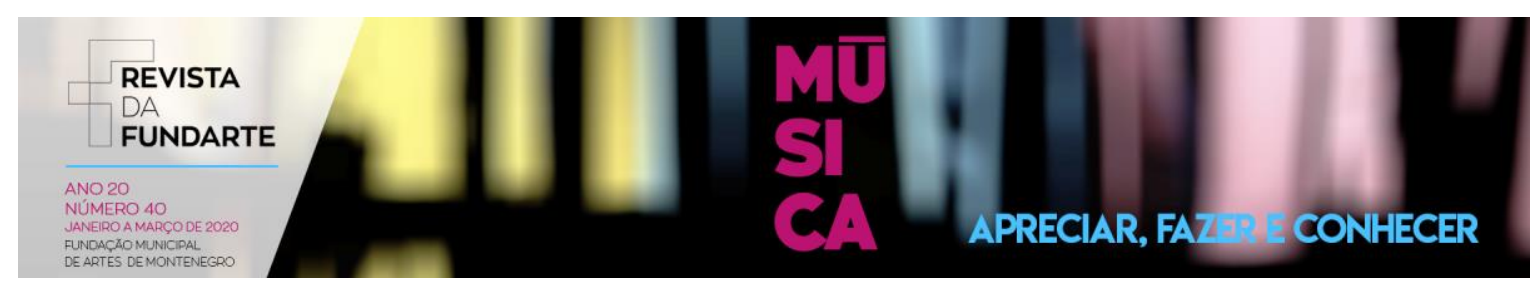

A quarta Etapa, Dimensões do Conhecimento em Música, destina-se aos processos de criação, expressão, reflexão, fruição, estesia e crítica, relacionadas ao processo de aprendizagem em Música, sobre a(s) música(s) e suas relações socioculturais globais.

A quinta Etapa, Habilidades Educativo-musicais, destina-se a apropriação dos mais diversos meios e formas de acesso à arte-música, incluindo suas interlocuções às demais linguagens (Artes Visuais, Dança e Teatro), quer seja de forma vivencial, exploratória, relacional e/ou analítica.

A sexta Etapa, Objetivos, destina-se a explanação sobre cada uma das metas a serem atingidas no desenvolvimento do ensino educativo-musical, em âmbito escolar.

A sétima Etapa, Conteúdos, relaciona o que se aprende musicalmente em âmbito escolar. Relaciona-se à disposição efetiva em que se trata o teor da aprendizagem educativo-musical.

E, por fim na oitava Etapa, Avaliação em Música, são expostos o que, como e quando se avalia no processo de apropriação do conhecimento educativo-musical, individual e/ou coletivo, em âmbito escolar por parte dos sujeitos imbricados na ação de ensino e aprendizagem musical.

Em considerando esses pressupostos iniciais, apresenta-se a seguir o Ciclo da Abordagem Curricular em Educação Musical.

ALMEIDA, Bruno Felix da Costa Almeida. .O ciclo da abordagem curricular em educação musical. Revista da FUNDARTE. Montenegro, p.87-109, ano 20, o 40, janeiro/março de 2019. Disponível em: http://.seer.fundarte.rs.gov.br/index.php/RevistadaFundarte/index> 31 de março de 2020 

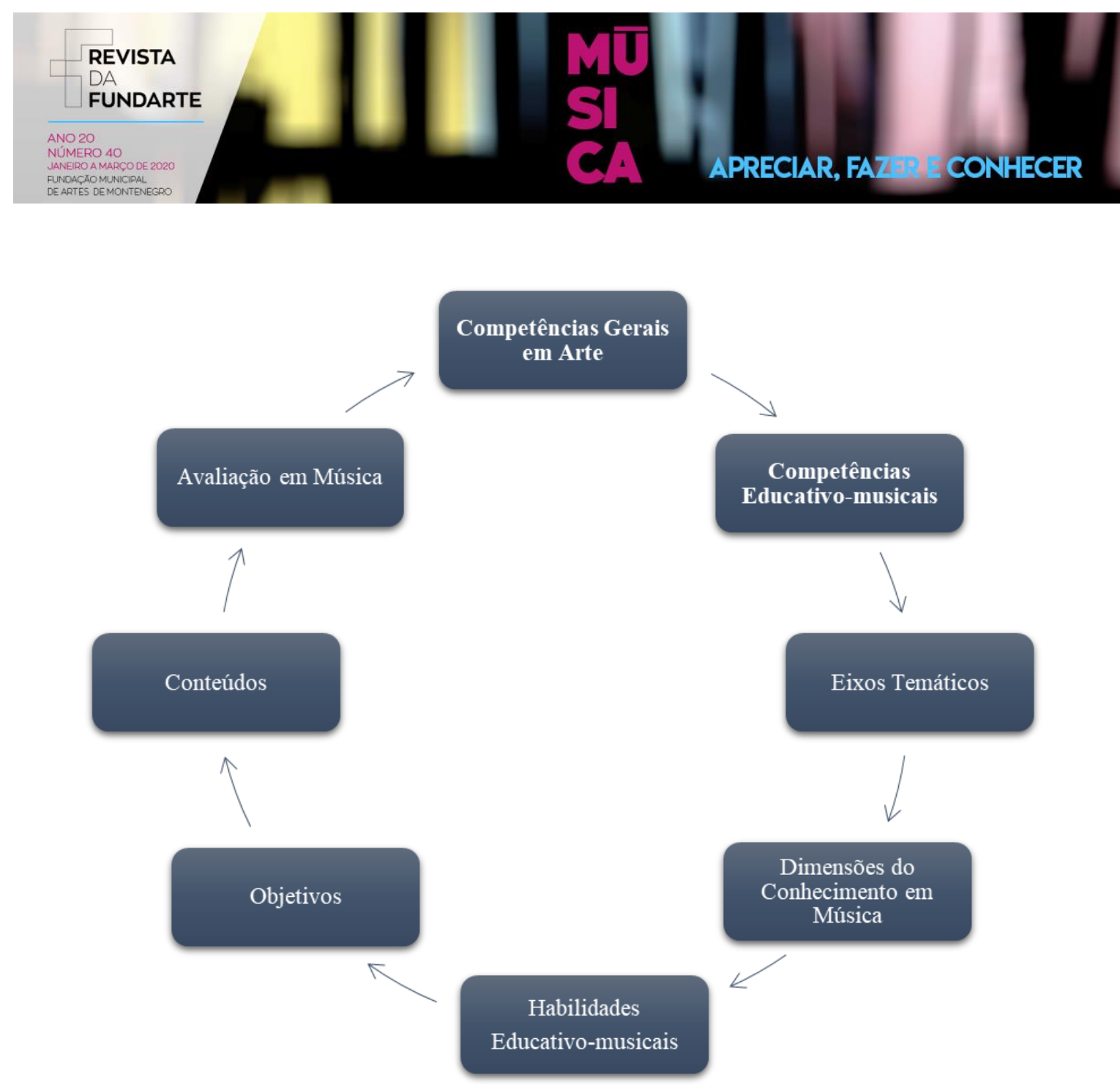

Figura 4 - Ciclo da Abordagem Curricular em Educação Musical. Elaboração nossa - O Ciclo da Abordagem Curricular em Educação Musical.

A proposta de utilização do Ciclo da Abordagem Curricular em Educação Musical tem sua importância tanto para a elaboração processual de um Currículo em Música entendido como Inicial, destinado para um ano em específico da Educação Básica, por exemplo, considerando cada uma das Etapas de desenvolvimento da Abordagem, quanto para que, ao final desta elaboração Curricular Inicial, seja viabilizada a elaboração de um outro Currículo para o próximo ano escolar em que se destina a continuidade do processo de ensino e aprendizagem musical.

Nesse sentido, entende-se que cada ano escolar proposto na Educação Básica brasileira tenha um Currículo em Música pensado individualmente, ao passo que, a partir do Texto do Currículo Inicial, o Currículo para o próximo ano escolar seja viabilizado, bem como os resultados de sua ação poderão ser norteadores e/ou repensados em considerando a sua aplicabilidade para o próximo ano letivo destinado ao ano escolar ao qual o Texto do Currículo Inicial compreende.

ALMEIDA, Bruno Felix da Costa Almeida. .O ciclo da abordagem curricular em educação musical. Revista da FUNDARTE. Montenegro, p.87-109, ano 20, o 40, janeiro/março de 2019. Disponível em: http://.seer.fundarte.rs.gov.br/index.php/RevistadaFundarte/index> 31 de março de 2020 


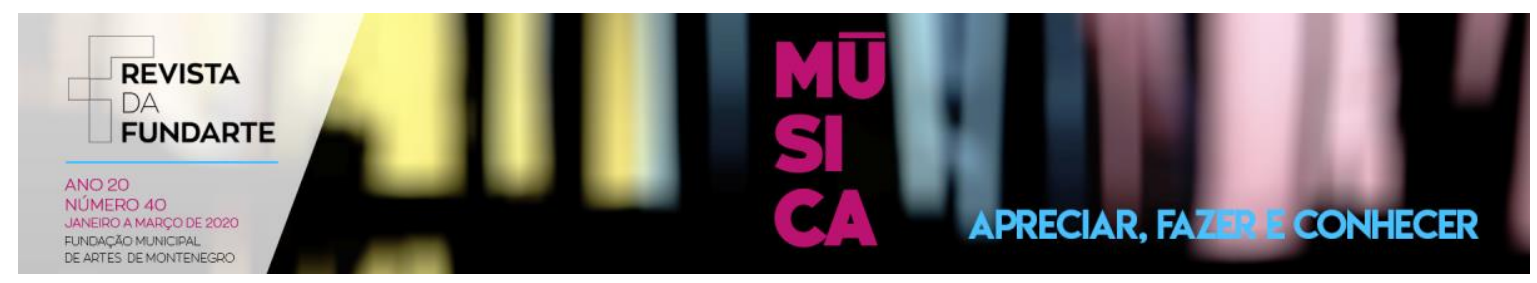

Em outras palavras, é possível considerar a seguinte situação-hipótese: Para o ensino de música em uma turma do primeiro ano do Ensino Fundamental - Anos Iniciais, o sujeito-propositor do Texto do Currículo apropria-se da "Abordagem do Ciclo de Políticas" (BOWE; BALL; GOLD, 1992; BALL, 1994) e das Etapas compreendidas pelo Ciclo da Abordagem Curricular em Educação Musical. Nesse sentido, são elaboradas/descritas as Competências Gerais em Arte, as Competências Educativo-musicais, os Eixos Temáticos, as Dimensões do Conhecimento em Música, as Habilidades Educativo-musicais, os Objetivos, os Conteúdos e o processo de Avaliação em Música, ambos considerando a realidade social à qual se destina o processo educativo-musical. Após este momento inicial de desenvolvimento do "Texto Político", conforme se compreende a partir de Bowe, Ball e Gold (1992), dar-se-á o seguimento ao próximo contexto, o do "Prática" (BOWE; BALL; GOLD, 1992).

Logo, após o desenvolvimento do Contexto do Texto (Currículo) no Contexto da Prática (Ação Educativa-musical), o sujeito-propositor do Currículo, que poderá ser ou não quem o viabilizou na ação do Contexto da Prática, poderá analisar, em considerando o "Contexto dos Efeitos" (BALL, 1994), os impactos deste durante e/ou após o seu desenvolvimento.

Portanto, será diante do "Contexto de Estratégia Política" (BALL, 1994), que o sujeito-propositor do Currículo poderá validar e/ou reformular o Texto Inicial do Currículo em Música, bem como propor, a partir dos efeitos obtidos e analisados, um Currículo para o próximo ano escolar, que nesta situação-hipótese configura o segundo ano do Ensino Fundamental - Anos Iniciais.

No entanto, o desenvolvimento da proposta curricular a partir da utilização do Ciclo da Abordagem Curricular em Educação Musical, poderá, também, acontecer em considerando um processo hipotético de aprendizagem para cada ano compreendido pela Educação Básica brasileira, viabilizando a elaboração no "Contexto da Produção do Texto Político" (BOWE; BALL; GOLD, 1992), o desenvolvimento de um Texto (Currículo em Música) para todos os anos escolares compreendidos pela Educação Básica brasileira.

ALMEIDA, Bruno Felix da Costa Almeida. .O ciclo da abordagem curricular em educação musical. Revista da FUNDARTE. Montenegro, p.87-109, ano 20, o 40, janeiro/março de 2019. Disponível em: http://.seer.fundarte.rs.gov.br/index.php/RevistadaFundarte/index> 31 de março de 2020 


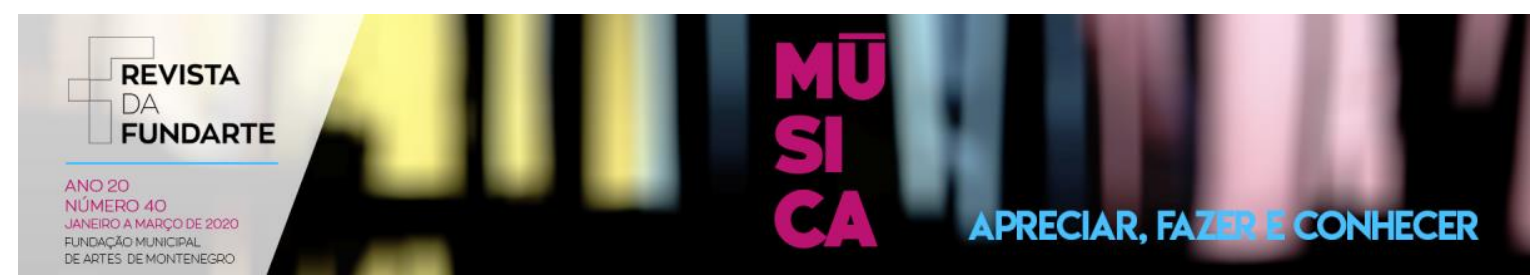

Foi a partir desta última situação-hipótese que o "Contexto da Produção do Texto Político" (BOWE; BALL; GOLD, 1992) se constituiu durante a realização da pesquisa de mestrado que o estudo compreendeu, empregando na Produção Textual do Currículo em Música, destinado a cada ano escolar, o Ciclo da Abordagem Curricular em Educação Musical, (re)iniciando-o no processo de aplicação do Ciclo na Educação Infantil - Nível I até o terceiro ano do Ensino Médio, os quais configuram os anos escolares ofertados pelo Colégio Gaspar Silveira Martins.

Endente-se, portanto, o imbricamento ou sobreposição da "Abordagem do Ciclo de Políticas" (BOWE; BALL; GOLD, 1992; BALL, 1994) ao Ciclo de Abordagem Curricular em Educação Musical, para a elaboração da proposta de um Currículo em Música que poderá ser operacionalizado nos anos escolares compreendidos pela Educação Básica brasileira.

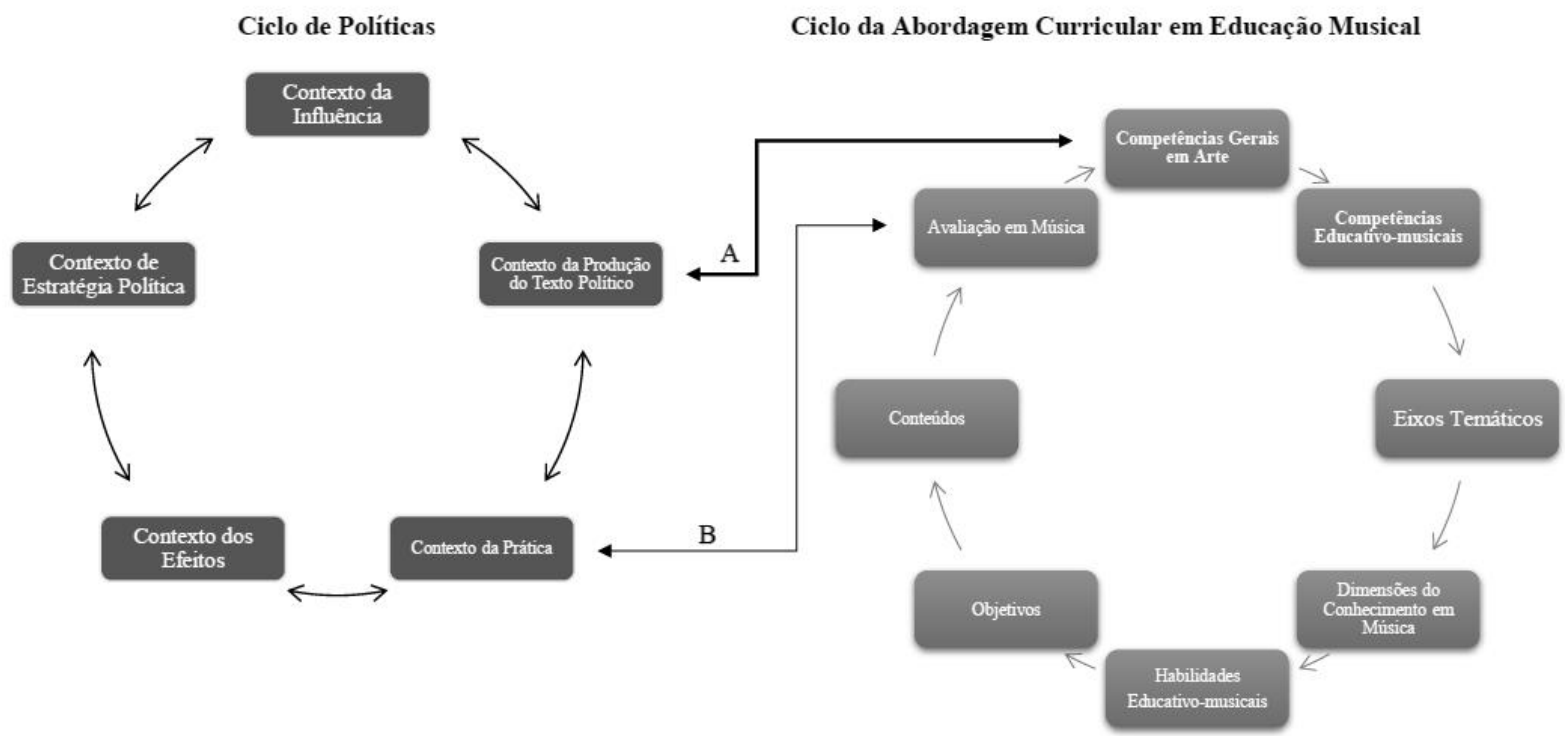

Figura 5 - Imbricamento da "Abordagem do Ciclo de Políticas" (BOWE; BALL; GOLD, 1992; BALL, 1994) ao Ciclo de Abordagem Curricular em Educação Musical.

O imbricamento relacionado entre a Abordagem do Ciclo de Políticas e o Ciclo de Abordagem do Currículo em Educação Musical consiste em primeiro momento na apropriação e no desenvolvimento do "Contexto da Influência" e do ALMEIDA, Bruno Felix da Costa Almeida. .O ciclo da abordagem curricular em educação musical. Revista da FUNDARTE. Montenegro, p.87-109, ano 20, o 40, janeiro/março de 2019. Disponível em: http://.seer.fundarte.rs.gov.br/index.php/RevistadaFundarte/index> 31 de março de 2020 


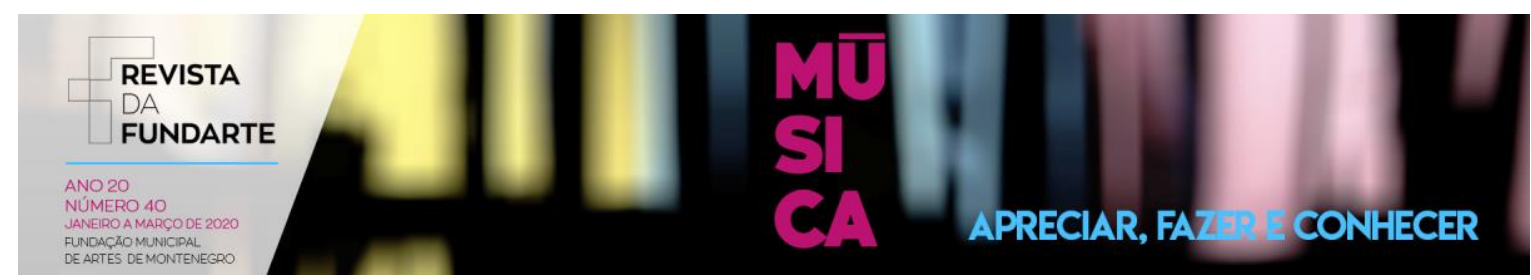

"Contexto da Produção do Texto Político" (BOWE; BALL; GOLD, 1992), dando seguimento, ao segundo momento às oito Etapas compreendidas pelo Ciclo de Abordagem do Currículo em Educação Musical (indicado pela seta A).

Ao finalizar todo o processo de produção do Texto Curricular destinado à um ano em específico da Educação Básica, seguindo as Etapas do Ciclo proposto, o sujeito-propositor do Currículo em Música poderá retornar à Abordagem do Ciclo de Políticas, dando seguimento ao terceiro momento configurado pelo "Contexto da Prática" (BOWE; BALL; GOLD, 1992) e, por consequência, aos demais Contextos subsequentes (indicado pela seta B), ou reiniciar o Ciclo de Abordagem do Currículo em Educação Musical para incitar a proposição Curricular do próximo ano escolar e assim sucessivamente, até a elaboração textual de toda a proposta Curricular em Música, aos anos previstos pelo processo curricular a ser elaborado pelo sujeitopropositor, (re)iniciando o Ciclo de Abordagem do Currículo em Educação Musical por quantas vezes forem necessárias.

Em considerando todo o processo textual do Currículo em Música a ser proposto e/ou operacionalizado nos anos escolares previstos pelo sujeito-propositor, retorna-se à "Abordagem do Ciclo de Políticas" (BOWE; BALL; GOLD, 1992; BALL, 1994) - indicado pela seta B. Sendo assim, o processo de elaboração e operacionalização do Currículo em Música poderá ser ciclicamente (re)planejado no imbricamento entre a "Abordagem do Ciclo de Políticas" (BOWE; BALL; GOLD, 1992; BALL, 1994) e o Ciclo de Abordagem do Currículo em Educação Musical, em prol do desenvolvimento do Currículo em Música em diferentes tempos e espaços músico-educacionais.

Em considerando as articulações explicitadas, o Contexto da Produção do Texto Político (Currículo em Música)² destinado ao Colégio Gaspar Silveira Martins, teve como referência o Currículo Inicial à Educação Infantil - Nível I. Após esta

\footnotetext{
2 O texto do "Currículo em Música" configura o Capítulo 7 - O Currículo em Música, da dissertação de Mestrado a qual este artigo é derivado, intitulada: "Do Texto ao Contexto, Da Imagem ao Som: Uma Proposta Histórico-Política para a Elaboração de um Currículo em Educação Musical”. O seu acesso se dá através do repositório de dissertações da biblioteca da Universidade Estadual do Rio Grande do Sul - Unidade Litoral Norte - Osório/RS.
}

ALMEIDA, Bruno Felix da Costa Almeida. .O ciclo da abordagem curricular em educação musical. Revista da FUNDARTE. Montenegro, p.87-109, ano 20, o 40, janeiro/março de 2019. Disponível em: http://.seer.fundarte.rs.gov.br/index.php/RevistadaFundarte/index> 31 de março de 2020 


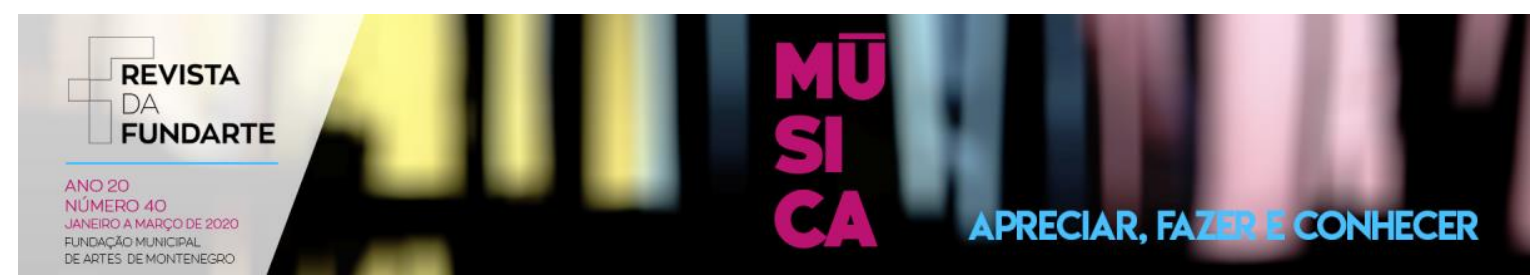

elaboração, seguiu-se a construção da proposição Curricular em Música à Educação Infantil - Nível II e sucessivamente à Educação Infantil - Nível III, aos 1ํㅜㄴ $2^{\circ}$, $3^{\circ} 4^{\circ}$ e $5^{\circ}$ anos do Ensino Fundamental - Anos Iniciais, aos 6ำ $7^{\circ}$, 8ํㅜ e $9^{\circ}$ anos do Ensino Fundamental - Anos Finais, e aos $1^{\circ}, 2^{\circ}$ e $3^{\circ}$ anos do Ensino Médio. E, em complemento à esta proposição, articulou-se a proposta de Atividades Complementares ao Currículo, considerando o Ensino de Música e suas Habilidades Específicas (Ensino do Canto Coral e de Instrumentos Musicais), destinado aos estudantes do $1^{\circ}$ ano do Ensino Fundamental - Anos Iniciais aos estudantes do $3^{\circ}$ ano do Ensino Médio.

\section{O Currículo em Música e a Teoria do Currículo: Algumas Considerações}

A relação da presente proposta teórico-metodológica para a elaboração do Currículo em Educação Musical e a Teoria do Currículo de Abeles, Hoffer e Klotman (1985) configura com ênfase na profundidade do desenvolvimento curricular em Música diante de sua implementação no Contexto da Prática (BALL; BOWE; GOLD, 1992).

À medida que o texto do Currículo em Música é implementado, no Contexto da Prática, em considerando as vivências e as percepções de quem o desenvolve nesse contexto, o impacto da ação educativo-musical poderá ser mais ou menos efetiva em se tratando do processo de ensino-aprendizagem musical.

A "preparação do currículo" (ABELES; HOFFER; KLOTMAN, 1985), o qual compreende o Contexto desta produção textual, é o primeiro impacto a ser levado em consideração, principalmente, ao que tange às habilidades e aos conteúdos selecionados ao contexto educativo. O modelo de currículo vislumbrado/proposto neste estudo, o Currículo Ideal, poderá ser um Currículo Formal ou Institucional, se aceito e integrado à proposição pedagógica da instituição de ensino para a qual poderá ser incitado.

Diante disso, os "fatores qualitativos" (ABELES; HOFFER; KLOTMAN, 1985), estão à mercê de quem interpreta e coloca no Contexto da Prática educativa o Currículo em Música. As tomadas de decisões, as prioridades consideradas, as ALMEIDA, Bruno Felix da Costa Almeida. .O ciclo da abordagem curricular em educação musical. Revista da FUNDARTE. Montenegro, p.87-109, ano 20, № 40, janeiro/março de 2019. Disponível em: http://.seer.fundarte.rs.gov.br/index.php/RevistadaFundarte/index> 31 de março de 2020 


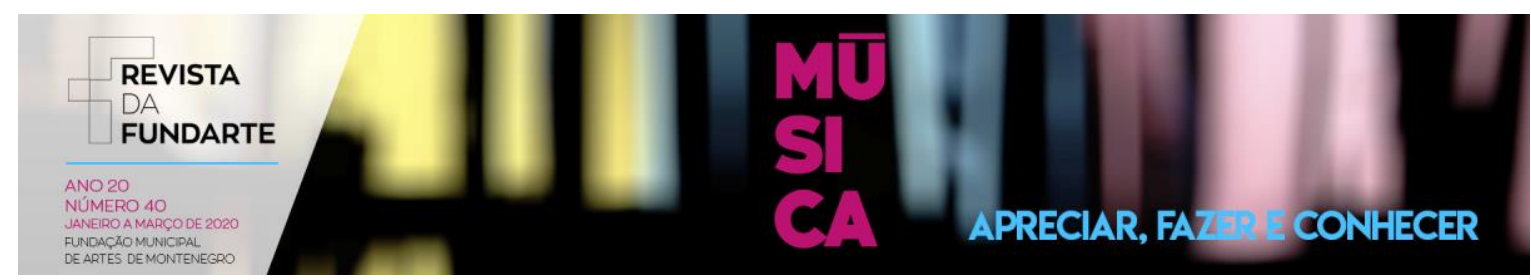

atitudes e as adequações efetivadas, bem como as barreiras e as facilitações à sua implementação, configuram alguns dos elementos envolvidos ao contexto do desenvolvimento curricular.

Por fim, as relações efetivas de profundidade das ações pedagógico-musicais estão, também, correlacionadas às "variáveis curriculares" (ABELES; HOFFER; KLOTMAN, 1985), em considerando nove itens específicos para a ação do processo de ensino e aprendizagem musical nesse contexto, quais sejam: as metas e os objetivos, os materiais utilizados para as ações pedagógicas, os conteúdos contemplados, as atividades de aprendizagens desenvolvidas, as estratégias de ensino escolhidas pelo professor de música, o desenvolvimento da avaliação, o agrupamento dessas proposições, além do tempo e do espaço de desenvolvimento pedagógico-musical.

Em considerando todos esses pressupostos previstos pela Teoria do Currículo de Abeles, Hoffer e Klotman (1985), em articulação com a Abordagem do Ciclo de Políticas de Bowe, Ball e Gold (1992) e Ball (1994) e o Ciclo da Abordagem Curricular em Música proposto nesse estudo, entende-se que as relações a serem estabelecidas entre o texto a ser proposto (o currículo em música) e a sua implementação no contexto prático, depende de sua interpretação em detrimento das condições viabilizadas ao desenvolvido da Educação Musical na instituição de Educação Básica o qual o acolhe.

\section{Referências:}

ABELES, Harold F. HOFFER, Charles R.; KLOTMAN, Robert H. Foundations of music education. New York: Schirmer Books, 1984.

BALL, Stephen J. Education reform: A critical and post-structural approach. Buckingham: Open university Press, 1994.

Sociologia das políticas educacionais e pesquisa crítico-social: uma revisão pessoal das políticas educacionais e da pesquisa em política educacional. In: BALL, Stephen J.; MAINARDES, Jefferson (Orgs.). Políticas educacionais: questões e dilemas. São Paulo: Cortez, 2011.

ALMEIDA, Bruno Felix da Costa Almeida. .O ciclo da abordagem curricular em educação musical. Revista da FUNDARTE. Montenegro, p.87-109, ano 20, no 40, janeiro/março de 2019. Disponível em: http://.seer.fundarte.rs.gov.br/index.php/RevistadaFundarte/index> 31 de março de 2020 


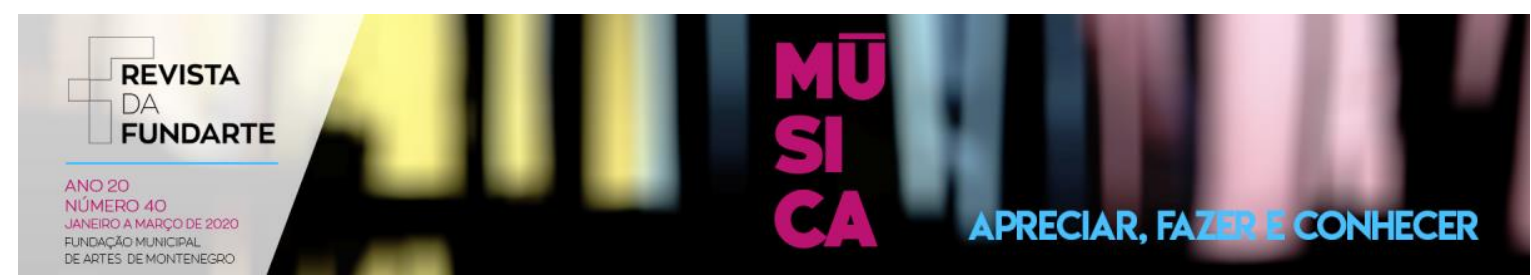

BOWE, Richard; BALL, Stephen J.; GOLD, Anne. Reforming education and changing schools: case studies in policy sociology. London: Routledge, 1992.

BRASIL. Ministério da Educação. Base Nacional Comum Curricular. 3ำ versão. Brasília: MEC, 2017. Disponível em: <basenacionalcomum.mec.gov.br/a-base> Acesso em: 05 de fev. 2020.

Ministério da Educação. Base Nacional Comum Curricular. Ensino Médio. Brasília: MEC, 2018. Disponível em: < basenacionalcomum.mec.gov.br/> Acesso em: 05 de fev. 2020.

LOPES, Alice Casimiro; MACEDO, Elisabeth. Contribuições de Stephen Ball para o estudo de políticas de currículo. In: BALL, Stephen J.; MAINARDES, Jefferson (Orgs.). Políticas educacionais: questões e dilemas. São Paulo: Cortez, 2011.

MAINARDES, Jefferson. Abordagem do ciclo de políticas: uma contribuição para a análise de políticas educacionais. Educ. Soc., Campinas, v. 27, n. 94, jan./abr, 2006. Disponível em: <www.scielo.br/pdf/es/v27n94/a03v27n94.pdf> Acesso em: 05 de fev. 2020.

MAINARDES, Jefferson; MARCONDES, Maria Inês. Entrevista com Stephen J. Ball: um diálogo sobre justiça social, pesquisa e política educacional. Educ. Soc., Campinas, v. 30, n. 106, jan./abr, 2009. Disponível em: $<$ www.scielo.br/pdf/es/v30n106/v30n106a15.pdf> Acesso em: 05 de fev. 2020.

McKERNAN, James. Currículo e imaginação: Teoria de processo, pedagogia e pesquisa-ação. Porto Alegre: Artmed, 2009.

SACRISTÁN, J. Gimeno. O currículo: uma reflexão sobre a prática. $3^{\mathrm{a}}$ ed. Porto Alegre: Penso, 2017.

SILVA, Tomaz Tadeu. O currículo como fetiche: a poética e a política do texto curricular. $2^{\mathrm{a}}$ Ed. Belo Horizonte: Autêntica, 2001.

ALMEIDA, Bruno Felix da Costa Almeida. .O ciclo da abordagem curricular em educação musical. Revista da FUNDARTE. Montenegro, p.87-109, ano 20, o 40, janeiro/março de 2019. Disponível em: http://.seer.fundarte.rs.gov.br/index.php/RevistadaFundarte/index> 31 de março de 2020 